\title{
Beta-Glucosidase: Key Enzyme in Determining Efficiency of Cellulase and Biomass Hydrolysis
}

Vijaya Rani, Saritha Mohanram, Rameshwar Tiwari, Lata Nain and Anju Arora*

Division of Microbiology, Indian Agricultural Research Institute, New Delhi 110 012, India

\begin{abstract}
Overall economics of the biomass to ethanol process is largely determined by the efficiency of biomass hydrolysis. Performance of cellulase cocktails used for saccharification of cellulose in biomass is often limited by lower amounts of $\beta$-glucosidases present, which catalyse hydrolysis of cellobiose, the product of endo and exocellulases to glucose. Inappropriate ratio of these enzymes in commercial cocktails leads to accumulation of cellobiose which inhibits the activity of cellulases. Thus, this rate limiting enzyme is of crucial importance in determining the efficiency of commercial cellulases. The saprophytic fungus Trichoderma sp., exploited for production of commercial cellulases, produces very minute quantities of $\beta$-glucosidases as compared to endo and exocellulases. However, several other organisms are known to produce $\beta$-glucosidases in higher quantities, over a broader substrate range. Strategies to get optimal ratio of exocellulases, endocellulases and $\beta$-glucosidases to enhance saccharification yields are, therefore, discussed. Appropriate levels of $\beta$-glucosidase activity in commercial cocktails have been obtained by supplementing with accessory $\beta$-glucosidases, transgenic approaches and by optimizing $\beta$-glucosidase production through manipulation of culture conditions. These approaches have resulted in achieving higher $\beta$-glucosidase activity in cellulase cocktails, facilitating higher sugar yields and thereby potentially improving enzymatic saccharification of biomass and eventually ethanol production.
\end{abstract}

Keywords: $\beta$-glucosidase; Saccharification; Lignocellulosic biomass

\section{Introduction}

Population is increasing at a fast pace and so is the demand, luxuries and, of course, energy consumption of a common man. Fossil fuel reserves being one of the major energy sources are diminishing at a fast rate, as a result of which fuel prices are increasing. Moreover, use of these fossil fuels emits greenhouse gases to the environment. With dwindling petroleum reserves and uncertain pricing, search for alternate forms of energy has gained unprecedented momentum. Amongst all renewable energy resources, energy from biomass is important not only for energy security but also for climate change mitigation. Bioenergy routes suggest that atmospheric carbon can be cycled through biofuels in carefully designed systems for sustainability. Significant potential exists for bioconversion of biomass, the most abundant and also the most renewable biomaterial on our planet, to ethanol. So, there is a move to adopt the environment friendly approach of using bioethanol as a transport fuel worldwide. In India, the Ministry of Petroleum on the $11^{\text {th }}$ of January, 2013 issued a gazette notification making mandatory for Oil Marketing Companies (OMCs) - Bharat Petroleum, Hindustan Petroleum and Indian Oil Corporation - to blend 5\% ethanol with petrol. Keeping in view the crisis of petroleum products, ethanol blending is necessary but there is still a wide gap between the ethanol required and produced. There are many technological gaps hindering the commercial production of biofuel of which costs as well as efficiency of hydrolytic enzymes are the major contributors [1].

\section{Biomass to Ethanol Process}

Bioethanol production had started long ago. The first attempt at commercialization of a process for ethanol production from wood was done in Germany in 1898 [2]. Currently ethanol is being produced from corn in the U.S. and from sugarcane in Brazil as well as India. But, being the world's second most populous country, India has many mouths to feed and therefore, ethanol production from these substrates does not appear to be advantageous. So, use of lignocellulosic biomass is the best way out to reduce the energy burden on a developing country like India, as it is cheap and easily available. Lignocellulosic biomass consists mainly of cellulose (33$40 \%)$, hemicellulose (20-25\%) and lignin (15-20\%) [3]. Cellulose and hemicelluloses are the most abundant biopolymeric materials on earth and constitute a major portion of plant cell wall comprising mainly of 5-carbon and 6-carbon sugars [4]. Of the three components of the lignocellulosic biomass, lignin is the most recalcitrant to digestion followed by hemicellulose and cellulose [5]. Therefore, conversion of this lignocellulosic biomass to ethanol involves various steps which include pre-treatment, saccharification, fermentation, separation and purification [6]. Pre-treatment causes increase in the accessible surface area, decrystallisation and depolymerisation of cellulose, hemicellulose and lignin to some extent. A variety of pre-treatment technologies are available like physical (grinding, milling, pyrolysis), physio-chemical (steam explosion, ammonia fibre explosion, $\mathrm{CO}_{2}$ explosion), chemical (ozonolysis, acid hydrolysis, alkaline hydrolysis, oxidative delignification, organosolv process) and biological (lignin degradation by brown rot and white rot fungi) [7]. Saccharification of complex polymers to simple sugars is carried out by the synergistic action of various hydrolytic enzymes like cellulases (exoglucanase, endoglucanase, $\beta$-glucosidase) and hemicellulases. Sugars formed are converted to ethanol by fermentation, predominantly carried out by yeast. Microorganisms used in the fermentation process should possess the ability to ferment both hexose and pentose sugars and should be

*Corresponding author: Anju Arora, Division of Microbiology, Indian Agricultural Research Institute, New Delhi 110 012, India, Tel: +91-11-258-484-31; E-mail: anjudev@yahoo.com

Received November 12, 2014; Accepted December 24, 2014; Published December 29, 2014

Citation: Rani V, Mohanram S, Tiwari R, Nain L, Arora A (2014) Beta-Glucosidase: Key Enzyme in Determining Efficiency of Cellulase and Biomass Hydrolysis. J Bioprocess Biotech 5: 197 doi: 10.4172/2155-9821.1000197

Copyright: @ 2014 Rani V, et al. This is an open-access article distributed under the terms of the Creative Commons Attribution License, which permits unrestricted use, distribution, and reproduction in any medium, provided the original author and source are credited. 
tolerant to lignocellulose derived metabolic inhibitors [8].

All the above steps require optimisation and they vary with the substrate used. Of these, hydrolysis is the most critical step, as complete saccharification and utilization of plant polymers is essential for efficient and economic production of bioalcohols. Existing technologies do not allow complete saccharification of plant polymers as there are many technological gaps hindering the action of currently available commercial cellulases. This step involves use of complex enzyme mixtures which are a costly input. The various means to maximise saccharification efficiency for enhanced ethanol production at reduced costs, as indicated in the Figure 1, include the following:

- $\quad$ Screening new organisms and bioprospecting for superior versions of key enzymes

- Using cellulosomes (multienzyme complex produced mainly by anaerobic bacteria) [9]

- Cellulase engineering using rational or irrational design [10]

- $\quad$ Protein engineering and high level expression in plants [6]

- $\quad$ Supplementing deficient enzymatic cocktails with accessory enzymes like $\beta$-glucosidase, xylanase, $\beta$-xylosidase, esterases [11]

\section{Selecting Enzymes for Augmenting Cellulase Cocktail}

The recalcitrant lignocellulose matrix has to be broken down to release cellulose and hemicelluloses for conversion to fuels and chemicals. This step can be performed chemically or enzymatically, the latter route being more appealing as the operating conditions are less harsh, less energy intensive and environment friendly [12]. A complete saccharification and utilization of plant polymers is critical for efficient and economic production of bioalcohols.

Cellulose is a linear polymer of glucose linked by $\beta-1,4$ linkage. It is acted upon by cellulases that consist of three major enzymes viz- endoglucanases (EC 3.2.1.4), exoglucanases (EC 3.2.1.91) and $\beta$-glucosidase (EC 3.2.1.21) [13]. These enzymes act in perfect synergism and tight regulation under natural conditions and break the cellulose polymer. Endoglucanases act randomly along the chain length, thereby producing new sites to be attacked by exoglucanases (or cellobiohydrolases $(\mathrm{CBH})$ ). Exoglucanases hydrolyse cellulose polymers from the terminal reducing or non-reducing ends producing mainly cellobioses. The cellobioses liberated are acted upon by $\beta$-glucosidases which convert them to glucose [14]. However, the proportion of $\beta$-glucosidase is meagre in most of the commercial cellulases and this causes not only accumulation of cellobioses but also feed-back inhibition of the cellulase enzyme complex. Hence, supplementation of $\beta$ - glucosidases in the enzymatic cocktails is suggested. Also, industrial level scale up of the process is not efficient as the current sources of commercial cellulases do not contain all the three components in optimum ratios and specific activities. In Trichoderma reseei, the proportion of these enzymes are endoglucanases (18\%), cellobiohydrolases (72\%) and $\beta$-glucosidases $(<1 \%)$, [8]. The $\beta$-glucosidase from Aspergillus niger is generally used to complement the cellulolytic cocktail of $T$. reseei [15]. These two genera of saprophytic fungi do not seem to produce wide arrays of biomass hydrolyzing cellulases in comparison to other plant pathogens. Therefore, augmenting enzymatic mixture with $\beta$-glucosidases or using microbes with desirable proportion of $\beta$-glucosidase in their cellulases will cause an increase in sugar yields which have been proved beyond doubt by various researchers [15].
Hemicelluloses are branched hetropolymers consisting of pentoses (xylose, arabinose), hexoses (glucose, mannose, galactose) and sugar acids of which xylan is the most abundant (70-90\%) [3]. Hemicellulose is mainly found on the outer surface of the cellulose fibres and act as a physical barrier that limits the accessibility of the cellulase enzymes to cellulose. Use of only cellulases in the enzymatic cocktail not only restricts its entry in the biomass but also leads to wastage of sugars trapped in hemicelluloses. Addition of hemicellulases in the enzymatic cocktails, hence, shows synergistic effect and not additive effect [16]. Hydrolysis of hemicelluloses can be done by enzymes like glycoside hydrolases, carbohydrate esterases, endo-hemicellulases, polysaccharide lyases which include endo-1,4- $\beta$-xylanases, $\beta$ xylosidase, $\beta$-mannase, $\beta$-mannosidase, $\alpha$-L-arabinofuranosidase etc. thereby suggesting use of various hemicellulases like xylanases, xylosidases in the enzymatic cocktail [11].

Lignin is most recalcitrant to digestion and consists of large amounts of phenolic acids such as coumaric acid and ferulic acid esterified to alcohol groups, in the form of coniferyl alcohol, sinapyl alcohol and coumaryl alcohol. Its degradation is carried out by various oxidoreductases like lignin peroxidase (EC 1.11.1.14), Mn peroxidase (EC 1.11.1.13), laccase (EC 1.10.3.2), etc. [17]. The action of these enzymes not only increases the accessibility of enzymes acting on the cellulose and hemicellulose components but also generates various oxidative species which may attack inhibitors produced during the production process and makes the process more effective. On the other hand, auto-oxidation of peroxidases may undermine their activity [18] Use of these enzymes in the cocktails for saccharification still requires further research.

Of all the enzymes that could be used for supplementing cellulases for enhancing saccharification efficiency, $\beta$ - glucosidase and xylanase are the most common and have been widely worked upon $[11,19]$. Therefore, screening new organisms and bioprospecting for superior versions of key enzymes and enzymes that act synergistically with existing commercial cellulases constitute an empirical approach towards increasing the cellulase efficiency and reducing the cost of ethanol production. Based on the understanding of lignocellulose matrix structure and mechanism of action of hydrolytic enzymes, it has been hypothesized that accessory enzymes - hemicellulases such as xylanases and $\beta$-glucosidases - can have a significant effect on the performance of cellulase cocktails [20]. Thus, supplementation of cellulase preparations is a useful strategy for maximising saccharification efficiency. Commercially, there is requirement of complex and coherent enzyme cocktails which act synergistically to unlock and saccharify polysaccharides from the lignocellulose complex to fermentable sugars to the greatest extent. These enzymes are the major costly inputs in the overall process and bringing down the cost of enzymatic saccharification step is a great challenge. In this review, we focus mainly on the role of $\beta$-glucosidases in unlocking the trapped sugars from complex polymers, ultimately resulting in enhanced ethanol yield.

\section{Organisms Producing Biomass Hydrolysing Glucohydrolases and $\beta$-Glucosidase}

Many organisms produce repertoires of hydrolytic enzymes which act in tandem to degrade components of biomass. Understanding the activity and synergism between these is fundamental in increasing the efficiency of the process [18]. Various groups of organisms including fungi, bacteria and even yeast produce $\beta$-glucosidase enzyme, each with its own advantage (Table 1). Fungi produce copious amounts of cellulases and hemicellulases extracellularly which facilitate their 


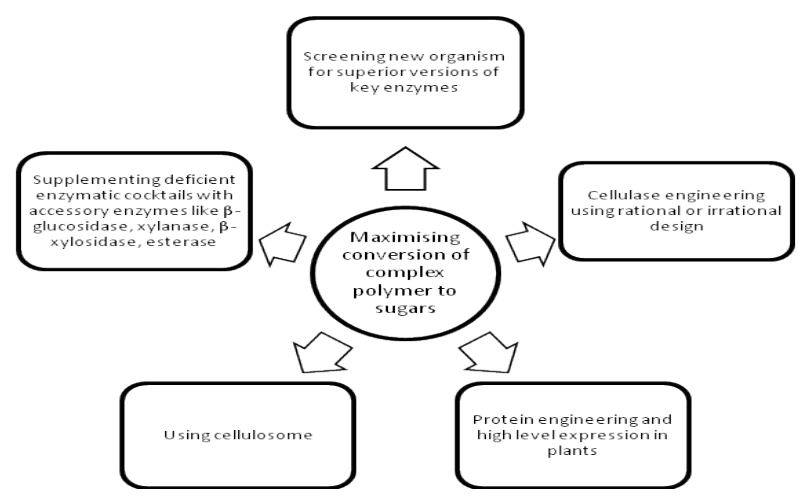

Figure 1: Various means for maximising saccharification efficiency

extraction and purification process. Besides, the enzymes produced are often less complex than bacterial glycoside hydrolases and can readily be used in developing recombinant organisms [10]. Most of the $\beta$-glucosidase producing bacteria isolated from Mediterranean soils have been found to belong to the phylum Proteobacteria [21]. Recently, bacteria are being exploited more because of their high growth rate and ability to produce multi-enzyme complex with increased function and synergy [10]. On the other hand, use of yeasts producing sufficient amounts of $\beta$-glucosidase enzymes opens the door for consolidated bioprocessing that can lead to lower-cost cellulosic ethanol production [22]. Penicillium decumbens 114-2, a filamentous fungus was found to produce more balanced extracellular lignocellulolytic enzyme with more of $\beta$-glucosidase of high specific activity and thus could cause hydrolysis to greater extent [23]. Commercial cellulase like Celluclast used in hydrolysis of lignocellulosic biomass has been investigated thoroughly and found to be deficient in $\beta$-glucosidase [24] which cause not only cellobiose to accumulate but also inhibit the activity of cellulase enzyme, thereby decreasing the saccharification efficiency [25]. The role of $\beta$-glucosidase in catalysing the rate limiting step in breakdown of cellulose to glucose suggests its supplementation in the enzymatic cocktail used for bioethanol production. Supplementation of $\beta$ - glucosidase from another source to cellulase obtained from Trichoderma and Penicillium spp. has been tried out and found to improve their ability to hydrolyse pretreated softwood lignocellulosics [26]. The act of isolating a high $\beta$-glucosidase producing strain with desirable properties and checking its synergism with commercial enzymes for saccharification is also common.

Many fungal strains like Trichoderma reesei, Phanerochaete chrysosporium etc. produce extracellular cellulases which are used for commercial cellulase production. It has also been found that nonpathogenic microorganisms like Trichoderma reesei encode fewer numbers of cellulases, xylanases and pectin lyases as compared to pathogenic organisms like Magnaporthe grisea, Fusarium graminearum, suggesting that these microorganisms can be potent sources of various hydrolytic enzymes [27]. $\beta$-glucosidases which are important for terminal hydrolysis of complex polymers are produced by a wide array of microorganism and can be intracellular, extracellular or membrane bound. Intracellular $\beta$-glucosidases are generally synthesised after exhaustion of carbon source in the medium [28]. Membrane bound $\beta$-glucosidases are however common in yeast. $\beta$-glucosidase from Aspergillus niger, which is generally used to complement the cellulolytic cocktail of Trichoderma reesei, are produced extracellularly leading to its easy separation and purification thus, reducing the cost of down streaming processing to great extent [29].

\section{Diversity of Naturally Occuring $\beta$-glucosidases through Metagenomics}

Complex microbial community analysis associated with different environmental habitats revealed that only a small proportion of microorganisms on earth can be cultivated in vitro, while majority of them remain unculturable [30]. These widespread unexplored microbes hold diverse group of biocatalysts that are stable and active under different extreme conditions [31]. Metagenomics, one of the key technologies based on the direct analysis of DNA from environmental samples, represents a strategy for discovering diverse biocatalysts encoded in nature [32]. This approach has been successfully used to identify biocatalysts with desired activities by applying low-throughput function-based screening of environmental DNA clone libraries [33]. After the advancement of third generation sequencing, the discovery of complete genes from metagenomic assemblies is still limited [34]. Congregated mining of the genetic information of $\beta$-glucosidase was explored across different environments including hydrothermal spring [35], wetlands [36], sludge [37], pulp wastewater [38], gut and rumen [39-41], anaerobic digesters [42] and compost [43].

Moreover, some detailed biochemical and molecular descriptions of metagenome-derived $\beta$-glucosidases are exposed to display their unique characteristics. The $\beta$-glucosidase Bgl1D derived from alkaline polluted soil is remarkably stable across a broad range of $\mathrm{pH}$ (5.5 to 10.5) and is not affected by high concentration of metal ions [37]. A thermostable glycosyl hydrolase 1 family $\beta$-glucosidase from archeal origin, isolated from hydrothermal spring, was active even at $105^{\circ} \mathrm{C}$ and also performed well in the presence of different reagents and solvents [35]. Another thermostable $\beta$-glucosidase was isolated from the functional screening of a metagenomic library from termite gut which showed its highest activity at $90^{\circ} \mathrm{C}$ [39]. One unique $\beta$-glucosidase with very high glucose tolerance ability of upto $1000 \mathrm{mM}$ was obtained from compost and it showed high transglycosylation activity by generating sophorose, laminaribiose, cellobiose, and gentiobiose [43]. Similar glucose tolerance was exhibited by the $\beta$-glucosidase derived from marine metagenome by retaining $50 \%$ of its activity even at $1000 \mathrm{mM}$ of glucose [44]. This enzyme is also active at high $\mathrm{NaCl}$ concentration signifying its origin from marine environment. Nam et al. [36] attempted successfully to engineer the $\beta$-glucosidase protein extracted from wetland in order to enhance stability and activity. All of these selected $\beta$-glucosidase proteins show very less protein similarity with the sequences available in database. These new entries from unculturable microbial systems aid to incorporate novel insights into the structure- function relationship and substrate recognition of $\beta$-glucosidase and reflect its versatile biotechnological applications.

\section{Transgenic Approaches to Enhance $\beta$-glucosidase and Biomass Hydrolysis}

Use of transgenics offers opportunities to combine several desirable traits into a single organism. Genetic engineering can be used to engineer microbes for high $\beta$-glucosidase producing ability. Pichia pastoris strain expressing a cDNA encoding $\beta$-glucosidase isolated from the buffalo rumen fungus Neocallimastix patriciarum was engineered for enhanced saccharification efficiency and was found to be better than the commercial $\beta$-glucosidase, Novozym 188 [45]. Hong Lee et al. [46] engineered a Saccharomyces cerevisiae strain expressing a cellodextrin transporter and an intracellular $\beta$-glucosidase from Neurospora crassa. This engineered strain can be used for simultaneous saccharification and fermentation with enhanced yield at reduced costs. Cellulolytic fungus $T$. reesei commonly used in commercial enzyme 


\begin{tabular}{|c|c|c|c|c|c|c|}
\hline Yeast & Location & Molecular & $\mathrm{Km}^{*}$ & $\mathrm{pH}$ & Temperature & References \\
\hline & & mass & $(\mathrm{mM})$ & optimum & optima $\left({ }^{\circ} \mathrm{C}\right)$ & \\
\hline & & (kDa) & & & & \\
\hline Candida cacaoi & Intracellular & 220 & 0.44 & 5.5 & 60 & {$[85]$} \\
\hline Metschnikowia pulcherrima & Intracellular & 400 & 1.5 & 4.5 & 50 & {$[86]$} \\
\hline Pichia pastoris & Intracellular & 275 & 0.12 & 7.3 & 40 & [87] \\
\hline Saccharomyces cerevisiae & Extracellular & 100 & 111.98 & 4.0 & 40 & [88] \\
\hline \multirow[t]{2}{*}{ Sporobolomyces singularis } & Cell & 146 & 1.96 & 3.5 & & [89] \\
\hline & associated & & & & & \\
\hline \multicolumn{7}{|l|}{ Fungi } \\
\hline Aspergillus uniguis & & 10 & 4.85 & 6.0 & 60 & {$[64]$} \\
\hline Penicillium decumbens & Extracellular & 120 & 0.0064 & $4.5-5.0$ & $65-70$ & [23] \\
\hline Penicillium piceum & Extracellular & 92 & 0.003 & 5.0 & 60 & [69] \\
\hline Penicillium citrinum & Extracellular & 72 & 1.20 & 5.0 & 70 & [90] \\
\hline Tolypocladium cylindrosporum & & & 0.85 & & & {$[61]$} \\
\hline Termitomyces clypeatus & Intracellular & 6.68 & & $5-8$ & 60 & [91] \\
\hline Rhizomucor miehei & & 82.29 & 0.12 & 5.0 & $68-70$ & [92] \\
\hline \multicolumn{7}{|l|}{ Bacteria } \\
\hline Micrococcus antarcticus & & 48 & 7.0 & 6.5 & 25 & [93] \\
\hline Thermoanaerobacter brockii & & & & & & [94] \\
\hline
\end{tabular}

Table 1: List of microorganisms producing $\beta$-glucosidases

preparation (Celluclast) with enhanced $\beta$-glucosidase and filter paper activity has been developed using strong artificial cellobiohydrolase 1 promoter [47]. A novel cellulase recycling method has been developed using a combination of cellulosomes of Clostridium thermocellum and Thermoanaerobacter brockii $\beta$-glucosidase [48]. Use of all these techniques could eliminate unwanted cost in ethanol production since cellulolytic enzymes account for $40-50 \%$ of the operational expenses [49].

Thus, genes responsible for expression of efficient and versatile $\beta$-glucosidase can be transferred to more industrially tractable and robust organisms to enhance the saccharification of the complex biomass polysaccharide.

\section{Enhancement in $\beta$-glucosidase Activity by Enzyme Immobilisation}

Immobilisation of $\beta$-glucosidase enzyme is an important tool for enhancement in its activity as immobilised enzyme facilitates efficient recovery and reuse of costly enzymes besides providing increased stability over wider ranges of temperature, $\mathrm{pH}$ and organic solvent [50]. Immobilisation of enzyme has been tried on various inorganic compounds and organic polymers like chelated magnetic metal ion nanoparticles [51], magnetic chitosan [52], alginate [53], polyacrylamide gel [54], agarose [55] and silica [56]. Immobilisation of the enzyme has been tried by both physical adsorption and covalent modification method, the main drawback being enzyme leakage and reduced activity, respectively. Besides, use of nanoparticles for enzyme immobilisation are in vogue these days as it offers additional advantage of high surface area to volume ratio which facilitates higher enzyme loading and enhanced biocatalytic efficiency for industrial application [57]. Immobilisation of $\beta$-glucosidase enzyme on magnetic $\mathrm{Fe}_{3} \mathrm{O}_{4}$ nanoparticles coupled with agarose showed enhanced activity as well as superior usability with more than $90 \%$ of enzyme activity retained even after 15 successive cycles [51]. A 10\% increase in saccharification efficiency has been observed on supplementation of immobilised $T$. reesei $\beta$-glucosidase enzyme on synthetic super paramagnetic magnetite to cellulases than supplementation of free $\beta$ - glucosidase enzyme [58]. Pretreatment of the immobilised $\beta$-glucosidases with cellobiose and glucose has been found to increase the activity of the enzyme but would surely add to the cost of fuel production and affect the economy of the process [59]. It has been also observed that immobilised enzymes differ in their physiochemical properties and increased thermo stability and different $\mathrm{pH}$ optima have been observed as compared to free enzyme [57]. In most of the cases, an increase in $K_{m}$ and decrease in $V_{\max }$ value have been reported on enzyme immobilisation but the advantage of being used multiple times with enhanced stability at extreme range of temperature and $\mathrm{pH}$ makes the process economically feasible $[53,60]$. The use of nanoparticles for enzyme immobilisation has been found to improve biochemical properties of the entrapped enzyme [56].

Therefore, enzyme immobilisation can be used as an efficient tool to combat the crisis faced due to high cost of the various hydrolytic enzymes and to economise biofuel production. Large scale trials for usage of immobilised $\beta$-glucosidase enzyme at industrial level are required to check the overall economy of the fermentable sugar production process.

\section{Accessory Enzyme $\beta$-glucosidase and Improvement in Biomass Hydrolysis}

The endogenous level of $\beta$-glucosidase activity in most cellulases is not sufficient to give high saccharification efficiencies. To rectify this limitation, supplementation of cellulases with accessory $\beta$-glucosidase from other sources having compatible activity parameters is a rational approach. Tolypocladium cylindrosporum syzx4, isolated from rotten corn stover, was found to extensively produce extracellular thermoacidophillic $\beta$-glucosidase using agro-industrial residues. This $\beta$-glucosidase when supplemented with commercial enzyme Celluclast from T. reesei was found to increase saccharification yield up to $88.4 \%$ underoptimalhydrolysiscondition [61].Four highlyactive $\beta$-glucosidase enzymes were isolated from ruminal bacteria of which LAB25g2 was found to be most active and could improve saccharification efficiency when used in combination with $\beta$-glucosidase deficient commercial $T$. reesei cocktail [15]. This was the first clear experimental evidence that $\beta$-glucosidase from ruminal bacterial metagenome can be of great use in hydrolysis of biomass. Thermostable $\beta$-glucosidases, isolated from Acremonium thermophilum (AtBG3) and Thermoascus aurantiacus 
(TaBG3), was found to cause greater hydrolysis of cellobiose as compared to $\beta$-glucosidases from Novozyme 188 (N188BG). However, both were found to be more sensitive to glucose inhibition as compared to N188BG. This showed that $\beta$-glucosidase tolerant to glucose tend to have low specificity constant for cellobiose hydrolysis. So, there has to be trade of between these two factors i.e. strength of glucose inhibition and affinity for cellobiose [62] for high sugar yield. $\beta$-glucosidases act to degrade the intermediate gluco-oligosaccharides produced by cellulase and concomitantly increase the efficiency of hydrolysis and thereby ethanol production.

Therefore, it can be stated that supplementation of $\beta$-glucosidase enzyme can greatly increase the rate of hydrolysis and ultimately increase the bioethanol yield. Along with screening of an efficient $\beta$-glucosidase producing strain, culture conditions like $\mathrm{pH}$, temperature, effect of methanol and other substrates for enzyme production should also be considered. But, mere usage of $\beta$-glucosidase for hydrolysis cannot enhance saccharification efficiency to great extent; the type of $\beta$-glucosidase selected for supplementation should also be taken care of.

\section{Desired Traits for Selecting $\beta$-glucosidases to be used for Supplementing Cellulases}

$\beta$-glucosidase activity and other parameters like tolerance to high concentration of glucose or ethanol, optimum temperature and $\mathrm{pH}$ range have been found to vary with culture conditions [63]. It is of imperial importance to use suitable substrate while undergoing $\beta$-glucosidase production as cheap and economic production of the concerned enzyme along with desirable properties for biomass hydrolysis determines the efficiency of the whole process.

Some important traits that should be considered in order to shortlist $\beta$-glucosidases for supplementation to hydrolytic cellulases are: insensitivity to high concentration of glucose or cellobiose, tolerance to high level of ethanol (more important in case of consolidated bioprocessing where enzyme production, saccharification and fermentation all occur in a single vessel), insensitivity to inhibitors like 2-furaldehyde and 5-hydroxymethyl-2-furaldehyde (produced during pre-treatment), high specific activity [64], low adsorption capabilities to lignin and wider temperature and $\mathrm{pH}$ range. Lower molecular weight isoforms of $\beta$-glucosidase have been found to be more glucose tolerant [64]. Changing the carbon source can also influence the glucose tolerance ability of $\beta$-glucosidases. Use of lactose has been found to improve the glucose tolerance ability of the enzyme [64]. Ethanol tolerance is another attribute that needs to be taken care of specially in the case of consolidated bioprocessing. $\beta$-glucosidase production in some yeast has been shown to be enhanced on addition of low concentration of ethanol as in the case of Dekkera intermedia [65], Candida molischiana [66]. The microorganism selected should be tolerant to the major inhibitors derived from lignocellulosic biomass pre-treatment such as furfural and hydroxyl methyl furfural. Yeast strain Clavispora NRRL Y-50464 resistant to these inhibitors has been reported [67]. An increase in $\beta$-glucosidase activity on addition of inorganic ions like $\mathrm{MnCl}_{2}$ by Phaffia rhodozyma has been reported [68] which emphasises the role played by different constituents of the culture media. Novel bifunctional glycoside hydrolase enzymes having properties of both $\beta$-glucosidase and $\beta$-xylosidase have also been reported in Penicillium piceum i.e. this enzyme can even act on xylotriose to produce xylobiose and D-xylose [69]. Research shows that xylooligomers are more powerful inhibitors of saccharification process than cellobiose and glucose [70]. Using enzymes with bifunctional activity would enhance the sugar yield in a dual fashion both by forming xylose sugar as well as by eliminating the inhibition caused by xylooligomers. These bifunctional $\beta$-glucosidases could produce better enzyme cocktails and greatly stimulate cellulase efficiency. The entrapment of cellulase enzyme particularly $\beta$-glucosidase enzyme onto lignin in the crude lignocellulosic biomass have been found to decrease sugar yield. $\beta$-glucosidase enzyme obtained from different organisms differ in their ability to get adsorbed onto the lignin component of the biomass as $\beta$-glucosidase obtained from $T$. reese $i$ has been found to be more susceptible to activity loss as compared to that obtained from Aspergillus niger [71]. Moreover, the ability to adsorb enzyme also differ with the composition of lignin, the type of biomass as well as pre-treatment method used [72]. High guaiacyl content than syringyl content in lignin confers increased ability to entrap enzyme and cause activity loss [73]. Enzymes having wider $\mathrm{pH}$ and temperature ranges seem to be a superior blender with the other hydrolytic enzymes used in the enzymatic cocktails. Chen et al. [23] isolated $\beta$-glucosidase from Penicillium decumbens whose temperature $\left(65-70^{\circ} \mathrm{C}\right)$ and $\mathrm{pH}$ (4.5-5.5) optima were found to be similar to that of cellulases obtained from $T$. reesei and hence was a superior blender in enzymatic cocktails containing cellulases from $T$. reesei [19].

Thus, the $\beta$-glucosidases used for supplementation in the saccharification of lignocellulosic biomass should have suitable properties in order to economise the production process and contribute to bring down the cost of ethanol to the extent that it can be used as a blender with petroleum products.

\section{Maximizing $\beta$-glucosidase Production through Manipulation of Cultural Parameters and Statistical Softwares}

Enzyme production using microorganisms employs use of complex nutrient medium having different components like carbon and nitrogen sources, inducers, surfactant, etc. Optimization of culture conditions helps in significant improvement in enzyme yield, saves time and is cost-effective. Various factors have been found to affect $\beta$-glucosidase production like temperature, $\mathrm{pH}$, incubation time, inoculum size, moisture content and substrate concentration [19,74]. Earlier, one variable-at-a-time method was used for optimization. But this method does not include the effect of interactions between the variables selected. Moreover, it requires numerous sequential experimental runs and is a time consuming and costly strategy [75]. In order to overcome these drawbacks, statistical methods such as Response Surface Methodology (RSM) can be used. This approach has been used by various workers for optimizing physiological conditions of fermentation involved in production of enzymes like Taq1endonuclease [76], polygalacturonase [77], cellulase [78]. It has also been used for optimising fermentation condition and maximizing $\beta$-glucosidase enzyme production where a number of factors like $\mathrm{pH}$, temperature, incubation time, type and amount of carbon and nitrogen source, surfactant, casamino acid, methanol were chosen of which methanol had the most pronounced effect on enzyme production [75] .

Once the conditions for maximum enzyme production are optimised, further optimization is required at the hydrolysis stage where sugar rich complex substrates and different combinations of hydrolytic enzymes are used. Other software's like Artificial Neural Network (ANN) and genetic algorithm are also available that can be used for process optimization.

\section{Application of $\beta$-glucosidase in Biorefinery and Other Industries}

$\beta$-glucosidases are ubiquitous in nature and can be found in 
bacteria, fungi, plants and animals. These enzymes have broad substrate specificity and therefore have huge applications across diverse industries. $\beta$-glucosidase molecules can cause both hydrolysis as well as reverse hydrolysis (transglycosylation) and lead to both cleavage and synthesis of glycosidic bond. The hydrolytic activities of these enzymes not only make them suitable for biofuel production but also for production of aglycone moiety (antitumor agent) and low viscosity gellan. The enzyme can also be used to remove bitterness from cooked soybean syrup [79], citrus fruit juices [80], and unripe olive [81] and even to detoxify cassava [82]. Deglycosylation (reverse hydrolysis) can cause degradation of betacyanins in beet root and release bioactive cellular metabolite with antitumor activity [83]. The enzymes are also involved in various biological pathways like degradation of structural and storage polysaccharides, host-pathogen interactions, cellular signalling and oncogenesis [84]. $\beta$-glucosidases can also cause synthesis of surfactant, o-alkyl-glucoside, by reverse hydrolysis. This surfactant is suitable for biological degradation and can be used as detergent in food industry, in cosmetic and pesticide formulation, and extraction of organic dyes. However, application of $\beta$ - glucosidases in biomass refining has gained unprecedented importance. All these applications require large scale production of the $\beta$-glucosidase enzyme in a cost effective manner.

\section{Future Prospect}

Most of the bioconversion processes used today does not allow complete saccharification of biomass. Hydrolysis of biomass can be enhanced by several approaches, one of which is by supplementation of cellulase complex with accessory enzymes. Traditional approach focuses on isolating high $\beta$-glucosidase producing microorganisms, isolating the enzyme and then supplementing it to commercial preparations. An alternate and more futuristic strategy is to engineer microbes for producing all major enzymes involved in hydrolysis of cellulose in optimum ratio, which would also decrease the expenditure greatly. Enzyme recycling can also help in reducing the cost of ethanol production to great extent.

\section{References}

1. Gao J, Weng H, Xi Y, Zhu D, Han S (2008) Purification and characterization of a novel endo-beta-1,4-glucanase from the thermoacidophilic Aspergillus terreus. Biotechnol Lett 30: 323-327.

2. Saeman JF (1945) Kinetics of Wood Saccharification - Hydrolysis of Cellulose and Decomposition of Sugars in Dilute Acid at High Temperature. Ind Eng Chem 37: 43-52.

3. Volynets B, Dahman Y (2011) Assessment of pretreatments and enzymatic hydrolysis of wheat straw as a sugar source for bioprocess industry. Int J Eng Environ 2: 427-446.

4. Sánchez OJ, Cardona CA (2008) Trends in biotechnological production of fuel ethanol from different feedstocks. Bioresour Technol 99: 5270-5295.

5. Howard RL, Abotsi E, Jansen EL, Howard S (2003) Lignocellulose biotechnology: issues of bioconversion and enzyme production. Afr J Biotechnol 2: 602-619.

6. Banerjee G, Scott-Craig JS, Walton JD (2010) Improving enzymes for biomass conversion: A basic research perspective. Bioenerg Res 3: 82-92.

7. Sun $Y$, Cheng $J$ (2002) Hydrolysis of lignocellulosic materials for ethanol production: a review. Bioresour Technol 83: 1-11.

8. Margeot A, Hahn-Hagerdal B, Edlund M, Slade R, Monot F (2009) New improvements for lignocellulosic ethanol. Curr Opin Biotechnol 20: 372-380.

9. Fontes CM, Gilbert HJ (2010) Cellulosomes: highly efficient nanomachines designed to deconstruct plant cell wall complex carbohydrates. Annu Rev Biochem 79: 655-681.

10. Maki M, Leung KT, Qin W (2009) The prospects of cellulase-producing bacteria for the bioconversion of lignocellulosic biomass. Int J Biol Sci 5: 500-516.
11. Kumar R, Wyman CE (2008) Effect of enzyme supplementation at moderate enzyme loading on initial glucose and xylose release from corn stover solids pre treated by leading technologies. Biotechnol Bioeng 102: 457-467.

12. Yang B, Dai Z, Ding SY, Wyman CE (2011) Enzymatic hydrolysis of cellulosic biomass. Biofuels 2: 421-450.

13. Mohanram S, Amat D, Choudhary J, Arora A, Nain L (2013) Novel perspectives for evolving enzyme cocktails for lignocellulose hydrolysis in biorefineries. Sustainable Chemical Processes 1: 15.

14. Martins LF, Kolling D, Camassola M, Dillon AJ, Ramos LP (2008) Comparison of Penicillium echinulatum and Trichoderma reesei cellulases in relation to their activity against various cellulosic substrates. Bioresour Technol 99: 1417-1424.

15. Del Pozo MV, Fernández-Arrojo L, Gil-Martínez J, Montesinos A, Chernikova TN, et al. (2012) Microbial $\beta$-glucosidases from cow rumen metagenome enhance the saccharification of lignocellulose in combination with commercial cellulase cocktail. Biotechnol Biofuels 5: 73.

16. Hu J, Arantes V, Saddler JN (2011) The enhancement of enzymatic hydrolysis of lignocellulosic substrates by the addition of accessory enzymes such as xylanase: is it an additive or synergistic effect? Biotechnol Biofuels 4: 36 .

17. Achyuthan KE, Achyuthan AM, Adams PD, Dirk SM, Harper JC, et al. (2010) Supramolecular self-assembled chaos: polyphenolic lignin's barrier to costeffective lignocellulosic biofuels. Molecules 15: 8641-8688.

18. Sweeney MD, Xu F (2012) Biomass converting enzymes as industria biocatalysts for fuels and chemicals: Recent Developments. Catalysts 2: 244-263.

19. Zimbardi A, Sehn C, Meleiro L, Souza F, Madui D, et al. (2013) Optimization of $\beta$-Glucosidase, $\beta$-Xylosidase and Xylanase Production by Colletotrichum graminicola under Solid-State Fermentation and Application in Raw Sugarcane Trash Saccharification. Int J Mol Sci 14: 2875-2902.

20. Hu J, Arantes V, Saddler JN (2011) The enhancement of enzymatic hydrolysis of lignocellulosic substrates by the addition of accessory enzymes such as xylanase: is it an additive or synergistic effect? Biotechnol Biofuels 4: 36 .

21. Moreno B, Canizares R, Nunez R, Benitez E (2013) Genetic diversity of $\beta$-glucosidase encoding genes as a function of soil management. Biol Ferti Soils 49: 735-745.

22. Liu Z, Weber S, Cotta M, Li S (2012) A new $\beta$-glucosidase producing yeas for lower-cost cellulosic ethanol production from xylose-extracted corncob residues by simultaneous saccharification and fermentation. Bioresour Techno 104: 410-441.

23. Chen M, Qin Y, Liu Z, Liu K, Wang F (2010) Isolation and characterization of a $\beta$-glucosidase from Penicillium decumbens and improving hydrolysis of corn cob residue by using it as cellulase supplementation. Enzyme Microb Technol 46: 444-449.

24. Arja M, John L, Vesa J, Raija L (2004) Three cellulase from Melanocarpus albomyces for textile treatment at neutral pH. Enzyme Microb Technol 34: 332-341.

25. Saha BC, Freer SN, Bothast RJ (1994) Production, Purification, and Properties of a Thermostable beta-Glucosidase from a Color Variant Strain of Aureobasidium pullulans. Appl Environ Microbiol 60: 3774-3780.

26. Berlin A, Gilkes N, Kilburn D, Bura R, Markov A, et al. (2005) Evaluation of novel fungal cellulase preparations for ability to hydrolyze softwood substratesevidence for the role of accessory enzymes. Enzyme Microb Technol 37: 175-184.

27. Gibson DM, King BC, Hayes ML, Bergstrom GC (2011) Plant pathogens as a source of diverse enzymes for lignocellulose digestion. Curr Opin Microbio 14: $264-270$

28. Lee J, Kwon KS, Hah YC (1996) Regulation of beta-glucosidase biosynthesis in Aspergillus nidulans. FEMS Microbiol Lett 135: 79-84.

29. Chauve M, Mathis H, Huc D, Casanave D, Monot F, et al. (2010) Comparative kinetic analysis of two fungal beta-glucosidases. Biotechnol Biofuels 3: 3 .

30. Vartoukian SR, Palmer RM, Wade WG (2010) Strategies for culture of 'unculturable' bacteria. FEMS Microbiol Lett 309: 1-7.

31. Fernández-Arrojo L, Guazzaroni ME, López-Cortés N, Beloqui A, Ferrer M (2010) Metagenomic era for biocatalyst identification. Curr Opin Biotechnol 21 725-733.

32. Li LL, McCorkle SR, Monchy S, Taghavi S, van der Lelie D (2009) Bioprospecting metagenomes: glycosyl hydrolases for converting biomass. Biotechnol Biofuels 2: 10 . 
33. Steele HL, Jaeger KE, Daniel R, Streit WR (2009) Advances in recovery of novel biocatalysts from metagenomes. J Mol Microbiol Biotechnol 16: 25-37.

34. Pareek CS, Smoczynski R, Tretyn A (2011) Sequencing technologies and genome sequencing. J Appl Genet 52: 413-435.

35. Schröder C, Elleuche S, Blank S, Antranikian G (2014) Characterization of a heat-active archaeal $\beta$-glucosidase from a hydrothermal spring metagenome. Enzyme Microb Technol 57: 48-54.

36. Nam KH, Kim SJ, Kim MY, Kim JH, Yeo YS, et al. (2008) Crystal structure of engineered beta-glucosidase from a soil metagenome. Proteins 73: 788-793.

37. Jiang C, Li SX, Luo FF, Jin K, Wang Q, et al. (2011) Biochemical characterization of two novel $\beta$-glucosidase genes by metagenome expression cloning. Bioresour Technol 102: 3272-3278.

38. Yang C, Niu Y, Li C, Zhu D, Wang W, et al. (2013) Characterization of a nove metagenome-derived 6-phospho- $\beta$-glucosidase from black liquor sediment. Appl Environ Microbiol 79: 2121-2127.

39. Wang Q, Qian C, Zhang XZ, Liu N, Yan X, et al. (2012) Characterization of a novel thermostable $\beta$-glucosidase from a metagenomic library of termite gut. Enzyme Microb Technol 51: 319-324.

40. Bao L, Huang Q, Chang L, Sun Q, Zhou J, et al. (2012) Cloning and characterization of two $\beta$-glucosidase/xylosidase enzymes from yak rumen metagenome. Appl Biochem Biotechnol 166: 72-86.

41. Zhu L, Wu Q, Dai J, Zhang S, Wei F (2011) Evidence of cellulose metabolism by the giant panda gut microbiome. Proc Natl Acad Sci U S A 108: 1771417719

42. Healy FG, Ray RM, Aldrich HC, Wilkie AC, Ingram LO, et al. (1995) Direct isolation of functional genes encoding cellulases from the microbial consortia in a thermophilic, anaerobic digester maintained on lignocelluloses. Appl Microbiol Biotechnol 43: 667-674.

43. Uchiyama T, Miyazaki K, Yaoi K (2013) Characterization of a novel $\beta$-glucosidase from a compost microbial metagenome with strong transglycosylation activity. $J$ Biol Chem 288: 18325-18334

44. Fang Z, Fang W, Liu J, Hong Y, Peng H, et al. (2010) Cloning and characterization of a beta-glucosidase from marine microbial metagenome with excellent glucose tolerance. J Microbiol Biotechnol 20: 1351-1358.

45. Chen HL, Chen YC, Lu MY, Chang JJ, Wang HT, et al. (2012) A highly efficient $\beta$-glucosidase from the buffalo rumen fungus Neocallimastix patriciarum W5. Biotechnol Biofuels 5: 24

46. Lee WH, Nan H, Kim HJ, Jin YS (2013) Simultaneous saccharification and fermentation by engineered Saccharomyces cerevisiae without supplementing extracellular $\beta$-glucosidase. J Biotechnol 167: 316-322.

47. Zhang J, Zhong Y, Zhao X, Wang T (2010) Development of the cellulolytic fungus Trichoderma reesei strain with enhanced beta-glucosidase and filter paper activity using strong artificial cellobiohydrolase 1 promoter. Bioresour Technol 101: 9815-9818

48. Waeonukul R, Kosugi A, Prawitwong P, Deng L, Tachaapaikoon C, et al (2013) Novel cellulase recycling method using acombination of Clostridium thermocellum cellulosomes and Thermoanaerobacter brockii $\beta$-glucosidase. Bioresour Technol 130: 424-430.

49. Xu Q, Singh A, Himmel ME (2009) Perspectives and new directions for the production of bioethanol using consolidated bioprocessing of lignocellulose. Curr Opin Biotechnol 20: 364-371.

50. Illanes A (2008) Enzyme Biocatalysis: Principles and Applications, Springer Science, New York, NY, USA.

51. Chen T, Yang W, Guo Y, Yuan R, Xu L, et al. (2014) Enhancing catalytic performance of $\beta$-glucosidase via immobilization on metal ions chelated magnetic nanoparticles. Enzyme Microb Technol 63: 50-57.

52. Zheng P, Wang J, Lu C, Xu Y, Sun Z (2013) Immobilized $\beta$-glucosidase on magnetic chitosan microspheres for hydrolysis of straw cellulose. Process Biochemistry 48: 683-687.

53. Keerti, Gupta A, Kumar V, Dubey A, Verma AK (2014) Kinetic Characterization and Effect of Immobilized Thermostable $\beta$-Glucosidase in Alginate Gel Beads on Sugarcane Juice. ISRN Biochemistry 2014: 1-8

54. Ortega N, Busto MD, Parez- Mateos M (1998) Optimisation of $\beta$-glucosidase entrapment in alginate and polyacrylamide gels. Bioresource Technology 64 105-111.
55. Silva TM, Pessela BC, Silva JCR, Lima MS, Jorge JA et al. (2014) Immobilization and high stability of an extracellular $\beta$-glucosidase from Aspergillus japonicus by ionic interactions. Journal of Molecular Catalysis B: Enzymatic 104: 95-100.

56. Reshmi R, Sugunan S (2013) Improved biochemical characteristics of crosslinked $\beta$-glucosidase on nanoporous silica foams. Journal of Molecular Catalysis B: Enzymatic 85-86: 111-118.

57. Verma ML, Chaudhary R, Tsuzuki T, Barrow CJ, Puri M (2013) Immobilization of $\beta$-glucosidase on a magnetic nanoparticle improves thermostability: application in cellobiose hydrolysis. Bioresour Technol 135: 2-6.

58. Vaenzuela R, Castro JF, Parra C, Baeza J, Duran N, et al. (2014) B-Glucosidase immobilisation on synthetic superparamagnetic magnetite nanoparticles and their application in saccharification of wheat straw and Eucalyptus globulus pulps. Journal of Experimental Nanoscience 9: 177-185.

59. Jung YR, Shin HY, Song YS, Kim SB, Kim SW (2012) Enhancement of immobilized enzyme activity by pretreatment of $\beta$-glucosidase with cellobiose and glucose. Journal of Industrial and Engineering Chemistry 18: 702-706.

60. Abraham RE, Verma ML, Barrow CJ, Puri M (2014) Suitability of magnetic nanoparticle immobilised cellulases in enhancing enzymatic saccharification of pretreated hemp biomass. Biotechnol Biofuels 7: 90.

61. Zhang Y, Chengyu L, Jingying T, Yu X, Lu J, et al. (2011) Enhanced saccharification of steam explosion pretreated corn stover by the supplementation of thermoacidophilic $\beta$-glucosidase from a newly isolated strain, Tolypocladium cylindrosporum syzx4. Afr J Microbiol Res 5: 2413-2421.

62. Teugjas H, Väljamäe $P(2013)$ Selecting $\beta$-glucosidases to support cellulases in cellulose saccharification. Biotechnol Biofuels 6: 105

63. García-Kirchner O, Segura-Granados M, Rodríguez-Pascual P (2005) Effect of media composition and growth conditions on production of beta-glucosidase by Aspergillus niger C-6. Appl Biochem Biotechnol 121-124: 347-59.

64. Rajasree KP, Mathew GM, Pandey A, Sukumaran RK (2013) Highly glucose tolerant $\beta$-glucosidase from Aspergillus unguis: NII 08123 for enhanced hydrolysis of biomass. J Ind Microbiol Biotechnol 40: 967-975.

65. Blondin B, Ratomahenina R, Arnaud A, Galzy P (1983) Purification and properties of the $\beta$-glucosidase of a yeast capable of fermenting cellobiose to ethanol: Dekkera intermedia Van Der Walt. European J Appl Microbiol Biotechnol 17: 1-6

66. Gonde P, Ratomahenina R, Arnaud A, Galzy P (1985) Purification and properties of an exocellular $\beta$-glucosidase of Candida molischiana (Zikes) Meyer Yarrow capable of hydrolyzing soluble cellodextrins. Can J Biochem Cell Biol 63: 1160-1166.

67. Liu ZL, Weber SA, Cotta MA, Li SZ (2012) A new $\beta$-glucosidase producing yeast for lower-cost cellulosic ethanol production from xylose-extracted corncob residues by simultaneous saccharification and fermentation. Bioresour Technol 104: 410-416.

68. Pera LM, Rubinstein L, Baigori MD, Figueroa L, Callieri DA (1999) Influence of manganese on cell morphology, protoplasts formation and $\beta$-D-glucosidase activity in Phaffia rhodozyma. FEMS Microbiology Letters 171: 155-160.

69. Gao L, Gao F, Zhang D, Zhang C, Wu G, et al. (2013) Purification and characterization of a new $\beta$-glucosidase from Penicillium piceum and its application in enzymatic degradation of delignified corn stover. Bioresour Technol 147: 658-661.

70. Qing Q, Wyman CE (2011) Hydrolysis of different chain length xylooliogmers by cellulase and hemicellulase. Bioresour Technol 102: 1359-1366.

71. Ko JK, Ximenes E, Kim Y, Ladisch MR (2014) Adsorption of enzyme onto lignins of liquid hot water pretreated hardwoods. Biotechnol Bioeng

72. Haven MO, Jorgensen $\mathrm{H}$ (2013) Adsorption of $\beta$-glucosidases in two commercia preparations onto pretreated biomass and lignin. Biotechnol Biofuels 6: 165

73. Guo F, Shi W, Sun W, Li X, Wang F, et al. (2014) Differences in the adsorption of enzymes onto lignins from diverse types of lignocellulosic biomass and the underlying mechanism. Biotechnol Biofuels 7: 38.

74. El-Naggar NEA, Haroun SA, Owis EA, Sherief AA (2014) Optimization of $\beta$-Glucosidase Production by Aspergillus terreus Strain Emoo 6-4 Using Response Surface Methodology Under Solid-State Fermentation. Preparative Biochemistry and Biotechnology.

75. Batra J, Beri D, Mishra S (2014) Response surface methodology based optimization of $\beta$-glucosidase production from Pichia pastoris. Appl Biochem Biotechnol 172: 380-393. 
Citation:Rani V, Mohanram S, Tiwari R, Nain L, Arora A (2014) Beta-Glucosidase: Key Enzyme in Determining Efficiency of Cellulase and Biomass Hydrolysis. J Bioprocess Biotech 5: 197 doi: 10.4172/2155-9821.1000197

Page 8 of 8

76. Nikerel E, Toksoy E, Kirdar B, Yildirim R (2005) Optimising medium composition for Taql endonuclease production by recombinant Escherichia coli cells using response surface methodology. Process Biochemistry 40: 1633-1639.

77. Tari C, Gogus N, Tokatli F (2007) Optimization of biomass, pellet size and polygalacturonase production by Aspergillus sojae ATCC 20235 using response surface methodology. Enzyme and Microbial Technology 40: 11081116.

78. Dave BR, Sudhir AP, Parmar P, Pathak S, Raykundaliya DP, et al. (2013) Enhancement of cellulase activity by a new strain of Thermoascus aurantiacus: Optimisation by statistical design response surface methodology. Biocat Agri Biotechnol 2: 108-115.

79. Hashimoto W, Miki H, Nankai H, Sato N, Kawai S, et al. (1998) Molecular cloning of two genes for beta-D-glucosidase in Bacillus sp. GL1 and identification of one as a gellan-degrading enzyme. Arch Biochem Biophys 360: 1-9.

80. Roitner M, Schalkmmer T, Pittner F (1984) Characterization of naringinase from Aspergillu sniger. Monatshefte für Chemie 115: 1255-1267.

81. Briante R, La Cara F, Febbraio F, Barone R, Piccialli G, et al. (2000) Hydrolysis of oleuropein by recombinant beta-glycosidase from hyperthermophilic archaeon Sulfolobus solfataricus immobilised on chitosan matrix. J Biotechnol 77: $275-286$

82. Gueguen P, Chemardin S, Pien A, Arnaud P, Galzy (1997) Enhancement of aromatic quality of muscat wine by the use of immobilised $\beta$-glucosidase. $J$ Biotechnol 55: 151-156.

83. Zakharova NS, Petrova TA (2000) [beta-Glucosidase of leaves and roots of the common beet Beta vulgaris]. Prikl Biokhim Mikrobiol 36: 458-461.

84. Bhatia Y, Mishra S, Bisaria VS (2002) Microbial beta-glucosidases: cloning properties, and applications. Crit Rev Biotechnol 22: 375-407.

85. Drider D, Pommares P, Chemardin P, Arnaud A, Galzy P (1993) Purification and properties of the endocellular beta-glucosidase of Candida cacaoi Buckley and Van Uden CBS 2020. J Appl Bacteriol 74: 473-479.
86. González-Pombo P, Pérez G, Carrau F, Guisán JM, Batista-Viera F, et al. (2008) One-step purification and characterization of an intracellular betaglucosidase from Metschnikowia pulcherrima. Biotechnol Lett 30: 1469-1475.

87. Turan $Y$, Zheng M (2005) Purification and characterization of an intracellular beta-glucosidase from the methylotrophic yeast Pichia pastoris. Biochemistry (Mosc) 70: 1363-1368

88. Villena MA, Iranzo JFÚ, Pérez AIB (2007) $\beta$-Glucosidase activity in wine yeasts: application in enology. Enz Microb Technol 40: 420-425.

89. Ishikawa E, Sakai T, Ikemura H, Matsumoto K, Abe H (2005) Identification, cloning, and characterization of a Sporobolomyces singularis betagalactosidase-like enzyme involved in galacto-oligosaccharide production. $J$ Biosci Bioeng 99: 331-339.

90. Ng IS, Li CW, Chan SP, Chir JL, Chen PT, et al (2010) High-level production of a thermoacidophilic beta-glucosidase from Penicillium citrinum YS40-5 by solid-state fermentation with rice bran. Bioresour Technol 101: 1310-1317.

91. Pal S, Banik SP, Ghorai S, Chowdhury S, Khowala S (2010) Purification and characterization of a thermostable intra-cellular beta-glucosidase with transglycosylation properties from filamentous fungus Termitomyces clypeatus. Bioresour Technol 101: 2412-2420

92. Krisch J, Takó M, Papp T, Vágvölgyi C (2010) Characteristics and potentia use of $\beta$-glucosidases from zygomycetes. Current research, technology and education topics in applied microbiology and microbial biotechnology 2: 891896.

93. Fan HX, Miao LL, Liu Y, Liu HC, Liu ZP (2011) Gene cloning and characterization of a cold-adapted $\beta$-glucosidase belonging to glycosyl hydrolase family 1 from a psychrotolerant bacterium Micrococcus antarcticus. Enzyme Microb Technol 49: 94-99.

94. Vaithanomsat $P$, Kosugi A, Apiwatanapiwat W, Thanapase W, Waeonukul $\mathrm{R}$, et al. (2013) Efficient saccharification for non-treated cassava pulp by supplementation of Clostridium thermocellum cellulosome and Thermoanaerobacter brockii $\beta$ - glucosidase. Bioresour Technol 132:383-286. 